\title{
Determining of biokinetic coefficients for the up flow anaerobic sludge blanket reactor treating sugarcane wastewater in hot climate conditions
}

\author{
Sana Mousavian ${ }^{1}$, Mahdi Seyedsalehi², Ombretta Paladino ${ }^{3}$ \\ Parisa Sharifi ${ }^{4}$, George Z. Kyzas ${ }^{5}$, Davide Dionisi ${ }^{6}$, Afshin Takdastan*
}

${ }^{1}$ Department of Environmental Engineering, Science and Research Branch, Islamic Azad University, Khouzestan, Iran

${ }^{2}$ Department of Environmental Engineering, Science and Research Branch, Islamic Azad University, Tehran, Iran

${ }^{3}$ Department of Civil, Chemical and Environmental Engineering, Università di Genova, Italy

${ }^{4}$ Department of Agronomy, Faculty of Agriculture, Urmia University, Iran

${ }^{5}$ Hephaestus Advanced Laboratory, Eastern Macedonia and Thrace Institute of Technology, Kavala, Greece

${ }^{6}$ Materials and Chemical Engineering group, School of Engineering, University of Aberdeen, Aberdeen, UK

*Department of Environmental Health Engineering, Ahvaz Jundishapur University of Medical Sciences, Ahvaz, Iran 


\begin{abstract}
Sugar extraction from sugarcane is a process which contains high volume of effluent, high levels of organic matter and biochemical oxygen demand (BOD). So, their disposal and discharge to rivers and environmental systems endangers the aquatic life. This research investigates and determines the kinetic coefficients of anaerobic treatment system (UASB) in sugarcane industrial wastewater treatment plant. $\mathrm{BOD}_{5}, \mathrm{COD}$, and TSS parameters in the input and output effluent of reactor were measured and the kinetic coefficients of $\mathrm{K}_{\mathrm{d}}, \mathrm{K}_{\mathrm{s}}$, $\mathrm{K}_{\max }$, and $\mu_{\max }$ were calculated using modified Monod Equations by determining the system design and operating parameters. The experimental results showed that rate of $K_{s}, Y, K_{d}$, $\mu_{\max }$, and $\mathrm{K}_{\max }$ for application of UASB process in wastewater treatment of sugarcane factories was $506.4 \mathrm{mg} / \mathrm{L}, 0.053 \mathrm{~g}$ VSS/g COD, $0.086 \mathrm{~d}^{-1}, 0.0049 \mathrm{~d}^{-1}$, and $0.055 \mathrm{~d}^{-1}$, respectively. The kinetic coefficients obtained in this research can be used in management, operation, and preparation of design principles of similar sugarcane treatment plants particularly in topical areas.
\end{abstract}

Keywords: Wastewater treatment; sugarcane industry, kinetic coefficients; UASB reactor; modified Monod equation 


\section{Introduction}

Untreated wastewater coming from industries or cities causes a negative impact on the environment. The effect of discharging wastewater directly to a water reservoir was noticed, in 2004 and 2007, when huge amount of death fish appeared in the lake Cocibolca (Nicaragua) (Nejad et al. 2013; Rodríguez-Gómez 2013). The process of sugar extraction from sugarcane discharges high volume of effluent, high levels of organic matter and biochemical oxygen demand (BOD). Therefore, their disposal and discharge to rivers and environmental systems endangers the environment and aquatic life (Mousavian et al. 2016). Sources of wastewater production in such factories include the wastewater resulting from transferring or washing beet or sugarcane, effluent from: (i) color bleaching resins, (ii) washing hardeners, (iii) washing the machinery and equipments, (iv) extraction of Molasses from sugar, (v) washing plant area, etc (Mousavian et al. 2016). Nearly, all types of wastewaters can be treated with biological methods by proper analysis and environmental control. To understand the characteristics of each biological process is necessary in order to ensure the provision of a suitable environment with effective control (Osaloo and Khoushfetrat 2004).

Anaerobic treatment is widely employed for treatment of most of the industrial wastewater containing high concentrations of soluble organic matter (Işik and Sponza 2005; Mostaed et al. 2010). Numerous anaerobic digesters exist and their classification is based on different criteria. There are low-, high- and ultrahigh- rate reactors if classification by hydraulic retention time (HRT) in used. Another important criterion is based on how (that means the manner) biomass is available in the process. Mainly, there are three ways: (i) attached on a support, (ii) suspended in the medium, and (iii) in granular sludge particles. In this study, reactors with granules as biomass will be mentioned. At first, the development of those reactors began with the up flow anaerobic sludge blanket (UASB) and then continued 
with some other types of reactors which mainly focused on the same criterion (Jaafari et al. 2017; Mirzaiy et al. 2012; Mosavian and Takdastan 2014; Seyedsalehi et al. 2017).

The UASB reactor is considered to be a major section of the "high-rate" anaerobic technology. At first years, UASB reactors were designed to treat industrial concentrated wastewaters, but nowadays the treatment also includes domestic wastewaters. The success of the UASB reactor concept relies on the establishment of a dense sludge bed in the bottom of the reactor, in which all biological process take place (Seghezzo 2004). A typical cylindrical UASB reactor is illustrated in Figure 1.

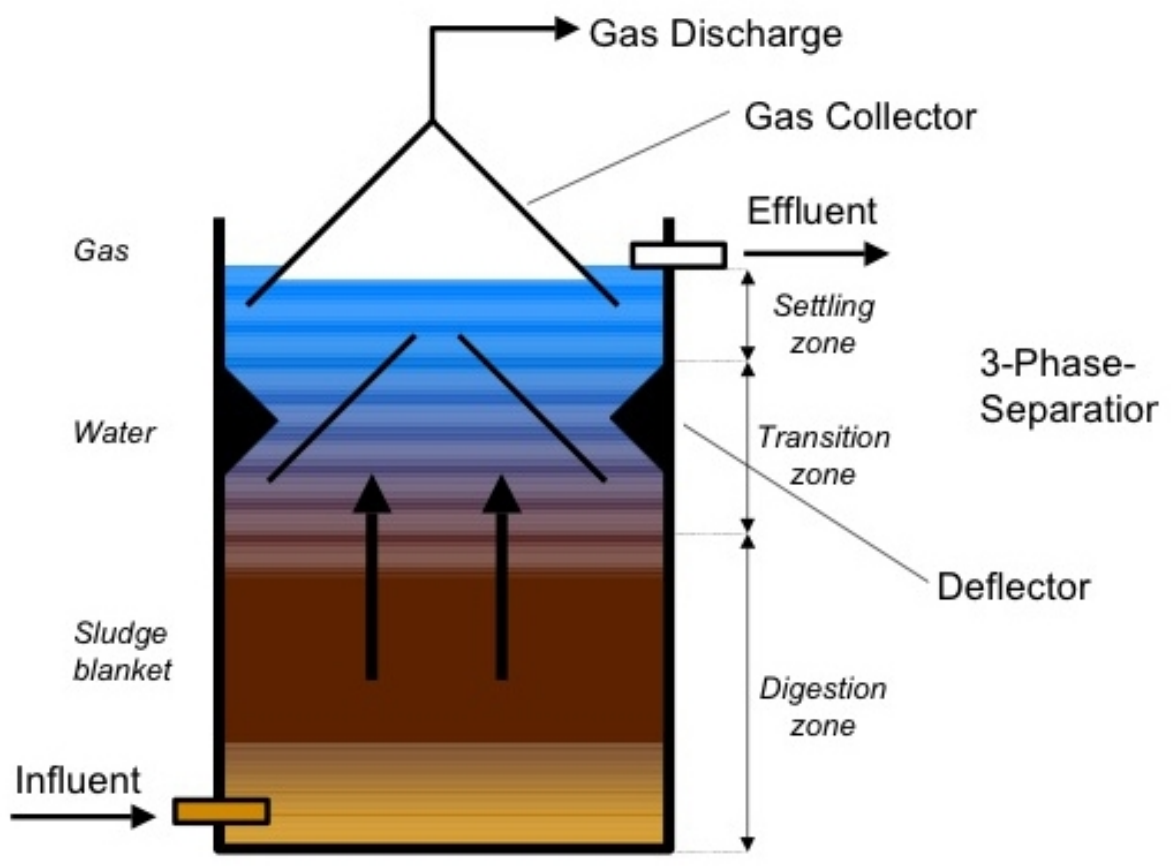

Figure 1. UASB reactor for wastewater treatment.

Much intention in the above scheme must be given in the feed inlet, the stages of gas separation, the collection of gas, and finally the effluent resulted. One thing that is major to say is that the design of the inlet feed and the stages of gas separation are unique to this type of reactors (UASB). Theory clearly reports that the design of the feed inlet must be done in such way in order to obtain/provide uniform distribution inside the reactor, avoiding channeling or creation of dead zones (Tchobanoglous et al. 2003). 
The UASB reactor process design is based on a special flow regime, the incoming wastewater is introduced into the reactor by means of a distribution system device. Wastewater passes upward through the sludge bed particles, enters into the settling zone via apertures between the phases separator elements, and it is uniformly discharged (Van Haandel et al. 2006). UASB reactor usually has short HRT and high volume load. As discussed above, it is necessary to ensure a uniformly influent distribution of wastewater. The kinetics of anaerobic conversion reaction in immobilized biomass is an important aspect in the biodegradation of organic matter.

Kinetic coefficients are used to control biological treatment processes and the models of the removal of organic matters and nutrients and also the microbiological growth are forecasted and estimated. Kinetic coefficients within the desired range of each biological treatment process are used for designing the same unit and the same specific wastewater in different places and are applied in the formulae of treatment plants designing. A study by (Takdastan et al. 2010) showed that identifying and describing Biological process types and analytical methods; process microbiology and biochemistry; and growth and substrate conversion patterns and kinetics, models, in SBR by adding chlorine and ozone dosage with sludge reduction. Estimation of kinetic parameters of heterotrophic biomass under aerobic conditions and characterization of wastewater for sequencing batch activated sludge modeling by heating some returned sludge (Fazelipour et al. 2011; Pazoki et al. 2010).

Mathematical models are used in fundamental research of anaerobic processes to examine the hypotheses, to determine the importance of relationships between variables to guide the experimental design and to evaluate the experimental results. These models also used to control and predict the treatment plant operation performance and to optimize the plant design and the results of scale-up pilot studies. At present, simplified models (involving only few variables) are easier to monitor and necessary for industrial applications in order to 
determine the kinetic constants (Iza et al. 1991; Takdastan et al. 2009). Amongst various mathematical models used to describe kinetics, the Monod model is the most and widely applied, based on the principle that the growth rate of microorganisms is proportional to the consumption of substrate. Moreover, through kinetic modeling, important information can be obtained, namely: (i) maximum specific rate of growth of biomass (max); (ii) saturation coefficient (Ks); (iii) decay coefficient (kd), and (iv) the yield coefficient (Y) (Campos et al. 2005). Monod type kinetic models have been widely used to describe the process kinetics of anaerobic digesters (Anderson et al. 1996).

Given the importance of the matter, some research has been done in this regard. The kinetic coefficients of UASB reactors in the treatment of wastewater of slaughter house (Tauzene and Milton 2011), ice-cream manufacturing plant (Borjai and Banks 1994), using fed batch reactors treating swine effluent (Masse and Massé 2010) and treating swine wastewater were calculated and determined by means of modified Monod equation.

In this study, the kinetic coefficients of UASB system in sugarcane factories were evaluated and examined in order to determine the appropriate operation of UASB treatment system as a suitable pretreatment before the active aerobic treatment system of sludge for the wastewater treatment of sugarcane industry. The kinetic coefficients obtained in this research can be used in management, operation, and design of similar treatment plants of sugarcane industry.

\section{Materials and Methods}

This study was conducted for 6 months in 2014-2015 in the wastewater of sugarcane factory in Shooshtarze located in Khuzestan Province (Iran) by means of UASB system at industrial scale. Since the plant activity is seasonal, the treatment plant is active about 6 months per year (with the beginning of sugarcane harvest at the end of September till the end 
of March). In this industry, wastewater is not produced constantly due to climatic conditions and delay in harvesting sugarcane and interruption to production. In order to control the flow fluctuations and for uniform quality of input effluent in terms of pollution load, the raw sewage is directed to the integration tank with retention time of 10 days. Then it is directed to modification tank for setting important parameters such as $\mathrm{pH}, \mathrm{P}, \mathrm{N}, \mathrm{COD}$, and essential micro-nutrients for the growth of anaerobic bacteria. After the injection of certain chemicals such as caustic soda $(\mathrm{NaOH})$, hydrochloric acid $(\mathrm{HCl})$, urea, and phosphoric acid $\left(\mathrm{H}_{3} \mathrm{PO}_{4}\right)$, the wastewater with discharge of $50 \mathrm{~m}^{3} / \mathrm{h}$ (at $37^{\circ} \mathrm{C}$ ) is transferred by means of wastewater distribution pipes from the reactor floor by the distance of $1.20 \mathrm{~cm}$ to the UASB reactor with width and length of $15.8 \mathrm{~m}$, height of $6 \mathrm{~m}$ and approximate volume of 15,000 $\mathrm{m}^{3}$. Organic compounds in effluents after combining with the mass of micro-organisms (which are in the form of dense granular particles with the approximate size of $0.14-0.50 \mathrm{~mm}$ ) will convert to methane and $\mathrm{CO}_{2}$. The produced biogases in UASB reactor are collected and burned by being directed towards the flame. UASB reactor was launched in October and the wastewater samples were taken twice a week in November, December, and January from the input and output points of the reactor by Grap-sample method. 7 samples were analyzed to determine parameters like BOD, COD, TSS, pH, VSS according to the standard methods of wastewater tests (APHA et al. 2005) and 21 samples were totally considered for each parameter.

\subsection{Parameters for determining kinetic coefficients}

(i) COD or $\left(\mathrm{S}_{0}\right)$ : concentration of raw effluent entering the reactor $(\mathrm{mg} / \mathrm{L})$

(ii) COD or (S): concentration of raw effluent leaving the reactor $(\mathrm{mg} / \mathrm{L})$

(iii) VSS or (X): concentration of microorganisms in the bottom of reactor (mg/L)

(iv) SRT or $\left(\theta_{c}\right)$ : cell retention time (day)

(v) HRT or $\left(\theta_{\mathrm{H}}\right)$ : hydraulic retention time (day) 


\subsection{Determining sampling points}

(i) Effluent entering the UASB reactor (modification tank effluent)

(ii) Effluent leaving the overflow of UASB reactor

(iii) Valve No. 2 of the reactor body (at a distance of $0.5 \mathrm{~m}$ from the bottom of reactor)

\subsection{Test method and experimental conditions}

Using the results of testing the qualitative parameters parameters of UASB reactor input and output, i.e. measured data of the parameters HRT $\left(\theta_{\mathrm{H}}\right)$, SRT $(\theta \mathrm{c})$, COD organic loading in $\mathrm{kg} / \mathrm{d}$ and eliminated BOD in $\mathrm{kg} / \mathrm{d}$, for each UASB system per month and by means of Minitab software and drawing the diagrams, the kinetic coefficients $\left(K_{s}, \mu_{\max }, K_{d}, Y, K_{\max }\right)$ were obtained by means of Minitab software, according to the modified Monod equation. The experimental conditions are given below:

(i) $100 \mathrm{~mL}$ of raw input and output effluent for determining the concentration of COD by means of COD meter spectrophotometer LOVIBOND-ET 108 according to the test No. 5250B (APHA et al. 2005).

(ii) $100 \mathrm{~mL}$ of output effluent from valve No.2 of the reactor body (Figure 2a) for determining the concentration of biomass in the reactor by conducting VSS experiment through gravimetric method by means of a digital scale and digital stainless steel oven according to the test No. 2540 E (APHA et al. 2005).

(iii) $25 \mathrm{~mL}$ of output effluent from the modification tank (Figure 2b) for measuring $\mathrm{pH}$ by means of pH meter JENWAY 3310 according to test No. 4500HB (APHA et al. 2005). 


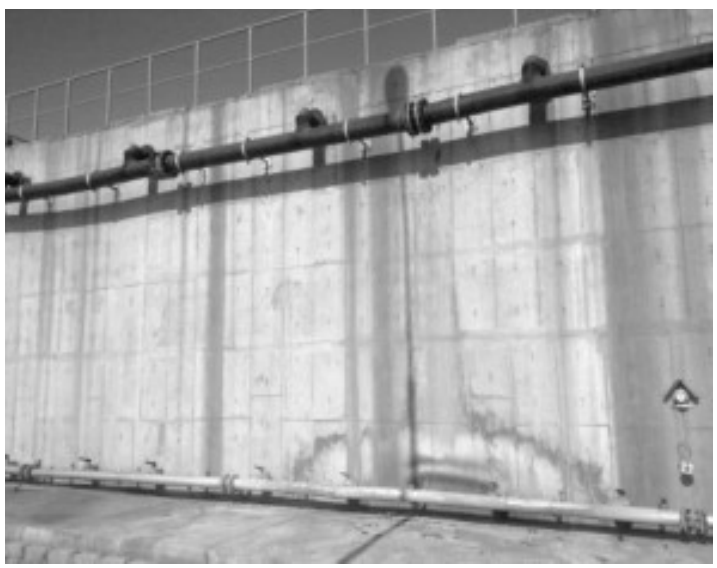

(a)

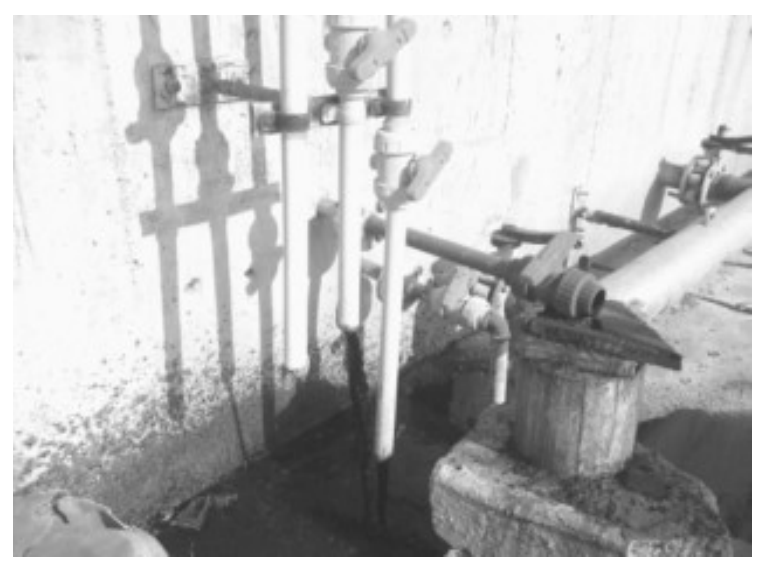

(b)

Figure 2. (a) UASB reactor in sugarcane industry; (b) the output valves from the UASB reactor.

\subsection{Determining method of kinetic coefficients}

In order to determine the kinetic coefficients $\mathrm{Y}$ and $\mathrm{K}_{\mathrm{d}}$ in this study, Eq. (1) was initially used (Işik and Sponza 2005):

$\left(\frac{\mathrm{S}_{0}-\mathrm{S}}{\theta_{\mathrm{H}} \cdot \mathrm{X}}\right)=\frac{1}{\mathrm{Y}} \cdot \frac{1}{\theta_{\mathrm{c}}}+\frac{1}{\mathrm{Y}} \cdot \mathrm{K}_{\mathrm{d}}$

The coefficients of $\mathrm{Y}$ and $\mathrm{K}_{\mathrm{d}}$ were estimated from Eq. (1) by drawing the regression diagram.

To determine the kinetic coefficients $K_{s}$ and $\mu_{\max }$, the $\left(\frac{S_{0}-S}{\theta_{H} \cdot X}\right)$ versus Eq. (2) was used (Işik and Sponza 2005).

$\left(\frac{\theta_{c}}{1+\theta_{c} \cdot K_{d}}\right)=\frac{K_{S}}{\mu_{\max }} \cdot \frac{1}{S}+\frac{1}{\mu_{\max }}$

The coefficients $K_{S}$ and $\mu_{\max }$ were estimated from $\left(\frac{\theta_{c}}{1+\theta_{c} \cdot K_{d}}\right)$ versus (1/S) by drawing the regression diagram, where $K_{\max }$ was calculated by means of Eq. (3) (Ișik and Sponza 2005). 
$\mathrm{K}_{\max }=\mu_{\max }$

The parameters used in above equations are the following:

Measured

$\checkmark$ (COD) $\mathrm{S}_{0}$ : concentration of input substrate (mg/L)

$\checkmark$ (COD) S: concentration of output substrate (mg/L)

$\checkmark$ X: concentration of microorganisms (mg/L)

$\checkmark \quad \theta_{\text {c: }}$ cell retention time (day)

$\checkmark \quad \theta_{\mathrm{H}}$ : hydraulic retention time (day)

Estimated

$\checkmark \quad K_{d}$ : cell death coefficient

$\checkmark \quad \mu_{\text {max }}$ : maximum specific growth rate

$\checkmark$ Y: yield coefficient

$\checkmark \mathrm{K}_{\text {max }}$ : maximum rate of organic matter decomposition

\section{Results and Discussion}

The results of the experiments in this study for determining the kinetic coefficients in November, December, and January are shown in Table 1. With the help of this kind of information and other tables the values of kinetic coefficients in November, December, and January were calculated. Table 2 shows the calculated values of solids retention time with considering $16 \%$ of waste sludge in average per day in November, December, and January. The hydraulic retention time of the effluent in reactor was considered as $12 \mathrm{~h}$ for the mentioned months. 
Table 1

The values obtained through the experiments of determining kinetic coefficients of November, December, and January.

\begin{tabular}{|c|c|c|c|c|c|c|c|c|c|c|c|c|}
\hline & \multicolumn{3}{|c|}{$X(m g / L)$} & \multicolumn{3}{|c|}{$C(d) \theta$} & \multicolumn{3}{|c|}{$\mathrm{S}(\mathrm{mg} / \mathrm{L})$} & \multicolumn{3}{|c|}{$S_{0}(m g / L)$} \\
\hline & January & December & November & January & December & November & January & December & November & January & December & November \\
\hline 1 & 6787 & 6636 & 5.5325 & 1.11 & 19.8 & 13 & 1500 & 1200 & 1700 & 4860 & 4120 & 3990 \\
\hline 2 & 5456 & 4563 & 4969 & 89.7 & 75.6 & 61.6 & 1640 & 1150 & 1400 & 4750 & 6323 & 3860 \\
\hline 3 & 3953 & 4393 & 4982 & 77.7 & 48.6 & 25.6 & 1300 & 1440 & 1650 & 3870 & 4234 & 4440 \\
\hline 4 & 3731 & 3985 & 4200 & 6 & 35.6 & 65.5 & 1370 & 1310 & 1900 & 4150 & 4188 & 4840 \\
\hline 5 & 9.3862 & 3611 & 3011 & 97.5 & 5.5 & 79.5 & 1600 & 1500 & 1980 & 4690 & 4352 & 4690 \\
\hline 6 & 3533 & 3481 & 2814 & 88.5 & 78.4 & 53.4 & 1720 & 1700 & 1700 & 4900 & 4383 & 4500 \\
\hline 7 & 3621 & 6400 & 2380 & 68.5 & 37.4 & 49.4 & 1520 & 1400 & 1200 & 4960 & 4600 & 3700 \\
\hline
\end{tabular}

Table 2

Solids retention time (SRT) in November, December, and January.

\begin{tabular}{cccc}
\hline & January & $\begin{array}{c}\text { SRT (d) } \\
\text { December }\end{array}$ & November \\
\hline 1 & 11.1 & 8.19 & 13 \\
2 & 7.89 & 6.75 & 6.61 \\
3 & 7.77 & 6.48 & 6.25 \\
4 & 6 & 6.35 & 5.65 \\
5 & 5.97 & 5.5 & 5.79 \\
6 & 5.88 & 4.78 & 4.53 \\
7 & 5.68 & 4.37 & 4.49 \\
\hline
\end{tabular}


To determine kinetic coefficients $\mathrm{Y}$ and $\mathrm{K}_{\mathrm{d}}$ in this study the values of $1 / \mathrm{SRT}\left(\theta_{\mathrm{c}}\right)$ are calculated using Eq. (1) and by means of available information in Table 1 and $\left(\frac{\mathrm{S}_{0}-\mathrm{S}}{\theta_{\mathrm{H}} \cdot \mathrm{X}}\right)$ are displayed in Table 3.

Table 3

Values of 1/SRT ( $\left.\theta_{c}\right)$ and $\left(\frac{S_{0}-S}{\theta_{H} \times X}\right)$ calculated in November.

\begin{tabular}{lcc}
\hline & $\left(\frac{\mathbf{S}_{\mathbf{0}}-\mathbf{S}}{\boldsymbol{\theta}_{\mathbf{H}} \times \mathbf{X}}\right)$ & \\
\hline 1 & 0.86 & 1/SRT $\left(\boldsymbol{\theta}_{\mathbf{C}}\right)$ \\
2 & 0.99 & 0.07 \\
3 & 1.12 & 0.122 \\
4 & 1.4 & 0.15 \\
5 & 1.8 & 0.16 \\
6 & 1.99 & 0.17 \\
7 & 2.1 & 0.172 \\
\hline
\end{tabular}

In Figure 3 the regression diagram between coefficients of $\mathrm{Y}$ and $\mathrm{K}_{\mathrm{d}}$ are calculated by means of it.

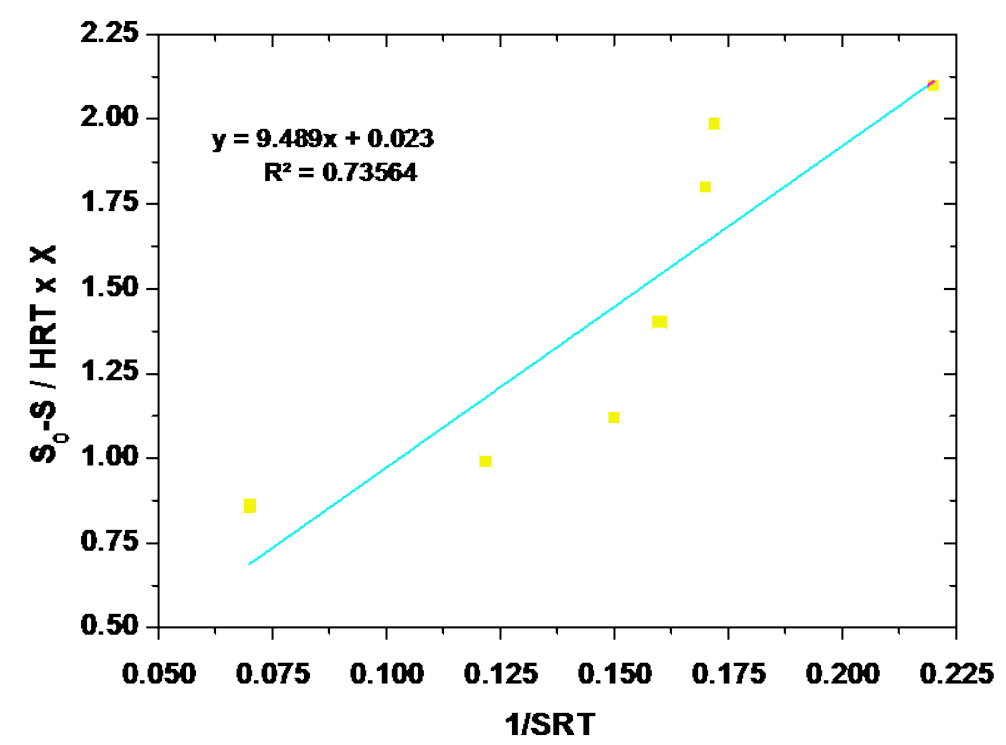

Figure 3. Linear regression between $1 / \mathrm{SRT}\left(\theta_{\mathrm{c}}\right)$ and $\left(\frac{\mathrm{S}_{0}-\mathrm{S}}{\mathrm{HRT} \cdot \mathrm{X}}\right)$ in November. 
Therefore, the values $\mathrm{Y}$ and $\mathrm{K}_{\mathrm{d}}$ were obtained as $\mathrm{Y}=0.105 \mathrm{~g} \mathrm{VSS} / \mathrm{g}$ COD and $\mathrm{K}_{\mathrm{d}}=0.024 \mathrm{~d}^{-1}$. In the next step, the kinetic coefficients of $\mu_{\max }$ and $\mathrm{K}_{\mathrm{s}}$ were determined by means of Eq. (2) and the calculated values are presented in Table 4.

\section{Table 4}

Values of $1 / \mathrm{S}$ and $\left(\frac{\operatorname{SRT}\left(\theta_{\mathrm{C}}\right)}{1+\operatorname{SRT}\left(\theta_{\mathrm{C}}\right) \times \mathrm{X}}\right)$ calculated in November.

\begin{tabular}{lcc}
\hline & $\left(\frac{\mathbf{S R T}\left(\boldsymbol{\theta}_{\mathbf{C}}\right)}{\mathbf{1 + \mathbf { S R T }}\left(\boldsymbol{\theta}_{\mathbf{C}}\right) \times \mathbf{X}}\right)$ & $\mathbf{1} / \mathbf{S}$ \\
\hline 1 & 345 & 0.00058 \\
2 & 348 & 0.0005 \\
3 & 376 & 0.00083 \\
4 & 361 & 0.00059 \\
5 & 367 & 0.00052 \\
6 & 368 & 0.00071 \\
7 & 393 & 0.0006 \\
\hline
\end{tabular}

The coefficients of $\left(\frac{\operatorname{SRT}\left(\theta_{C}\right)}{1+\operatorname{SRT}\left(\theta_{C}\right) \times X}\right)$ and $1 / \mathrm{S}$ are drawn and in Figure 4 the regression curve between of $\mu_{\max }$ and $K_{s}$ are calculated by means of it. 


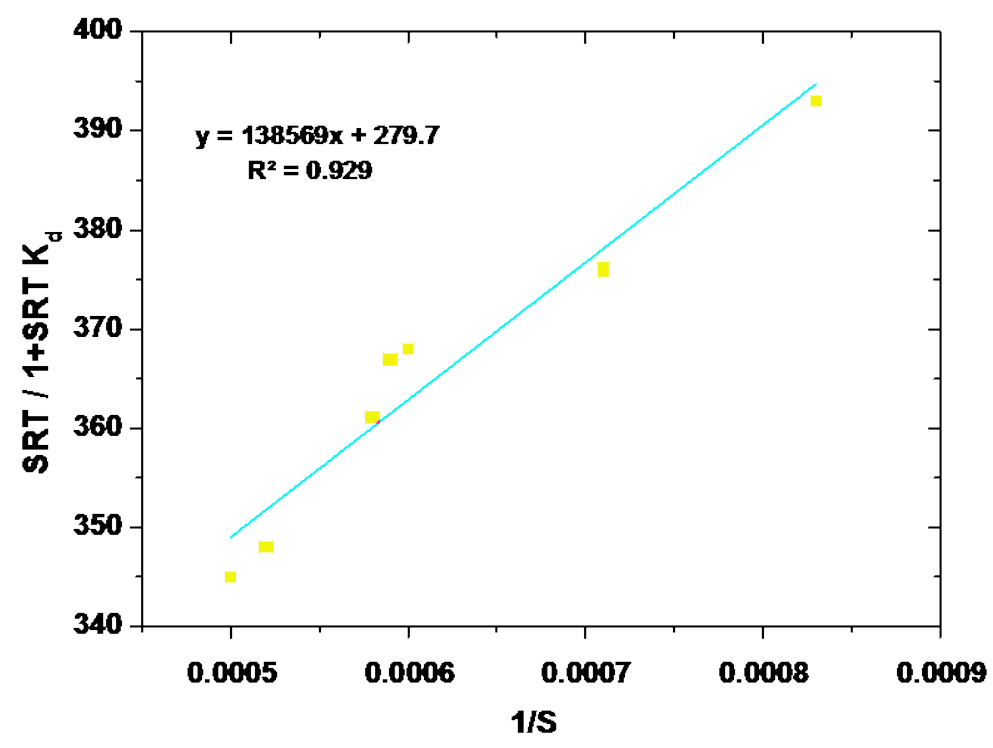

Figure 4. Linear regression between $1 / \mathrm{S}$ and $\left(\frac{\operatorname{SRT}\left(\theta_{C}\right)}{1+\operatorname{SRT}\left(\theta_{C}\right) \times X}\right)$ in November.

Therefore, the values of $K_{s}$ and $\mu_{\max }$ were calculated as $K_{s}=484.9 \mathrm{mg} / \mathrm{L}$ and $\mu_{\max }=0.0035 \mathrm{~d}^{-1}$. $K_{\max }$ was also calculated from Eq. (3) equal to 0.033 .

In the same way the calculated values of $\left(\frac{1}{\mathrm{~S}}, \frac{\mathrm{SRT}\left(\theta_{\mathrm{C}}\right)}{1+\mathrm{SRT}\left(\theta_{\mathrm{C}}\right) \times \mathrm{X}}\right)$ are displayed in Tables 5 and 6.

Table 5

Values of $\left(\frac{1}{S}, \frac{\operatorname{SRT}\left(\theta_{C}\right)}{1+\operatorname{SRT}\left(\theta_{C}\right) \times X}\right)$ and $\left(\frac{S_{0}-S}{\operatorname{HRT}\left(\theta_{H}\right) \times X}, \frac{1}{\operatorname{SRT}}\right)$ calculated in

December.

\begin{tabular}{ccccc}
\hline & $\left(\frac{\mathbf{S R T}\left(\boldsymbol{\theta}_{\mathbf{C}}\right)}{\mathbf{1 + S R T}\left(\boldsymbol{\theta}_{\mathbf{C}}\right) \times \mathbf{X}}\right)$ & $\mathbf{1} / \mathbf{S}$ & $\left(\frac{\mathbf{S}_{\mathbf{0}}-\mathbf{S}}{\mathbf{H R T}\left(\boldsymbol{\theta}_{\mathbf{H}}\right) \times \mathbf{X}}\right)$ & \\
\hline 1 & 99.3 & 0.00058 & 0.88 & 0.122 \\
2 & 101 & 0.00066 & 1.1 & 0.148 \\
3 & 104 & 0.00069 & 1.22 & 0.154 \\
4 & 105 & 0.00071 & 1.38 & 0.157 \\
5 & 105.8 & 0.00076 & 1.44 & 0.18 \\
6 & 107 & 0.00083 & 1.58 & 0.2 \\
7 & 112 & 0.00086 & 1.6 & 0.22 \\
\hline
\end{tabular}


Table 6

Values of $\left(\frac{1}{S}, \frac{\operatorname{SRT}\left(\theta_{C}\right)}{1+\operatorname{SRT}\left(\theta_{C}\right) \times X}\right)$ and $\left(\frac{S_{0}-S}{\operatorname{HRT}\left(\theta_{H}\right) \times X}, \frac{1}{\operatorname{SRT}}\right)$ calculated in

January.

\begin{tabular}{ccccc}
\hline & $\left(\frac{\mathbf{S R T}\left(\boldsymbol{\theta}_{\mathbf{C}}\right)}{\mathbf{1}+\mathbf{S R T}\left(\boldsymbol{\theta}_{\mathbf{C}}\right) \times \mathbf{X}}\right)$ & $\mathbf{1 / S}$ & $\left(\frac{\mathbf{S}_{\mathbf{0}}-\mathbf{S}}{\mathbf{H R T}\left(\boldsymbol{\theta}_{\mathbf{H}}\right) \times \mathbf{X}}\right)$ & \\
\hline 1 & 298.5 & 0.00058 & 0.99 & 0.090 \\
2 & 299 & 0.0006 & 1.14 & 0.126 \\
3 & 300 & 0.00062 & 1.3 & 0.128 \\
4 & 309 & 0.00065 & 1.49 & 0.166 \\
5 & 310.8 & 0.00066 & 1.6 & 0.167 \\
6 & 315.6 & 0.00072 & 1.8 & 0.17 \\
7 & 317 & 0.00076 & 1.9 & 0.176 \\
\hline
\end{tabular}

Figures 5 and 7 display the linear regression between 1/SRT and $\left(\frac{S_{0}-S}{\operatorname{HRT}\left(\theta_{H}\right) \times X}\right)$ in December and January. In Figures 6 and 8, the regression curves between in $\left(\frac{S_{0}-S}{\operatorname{HRT}\left(\theta_{H}\right) \times X}\right)$ and 1/S in mentioned months are shown.

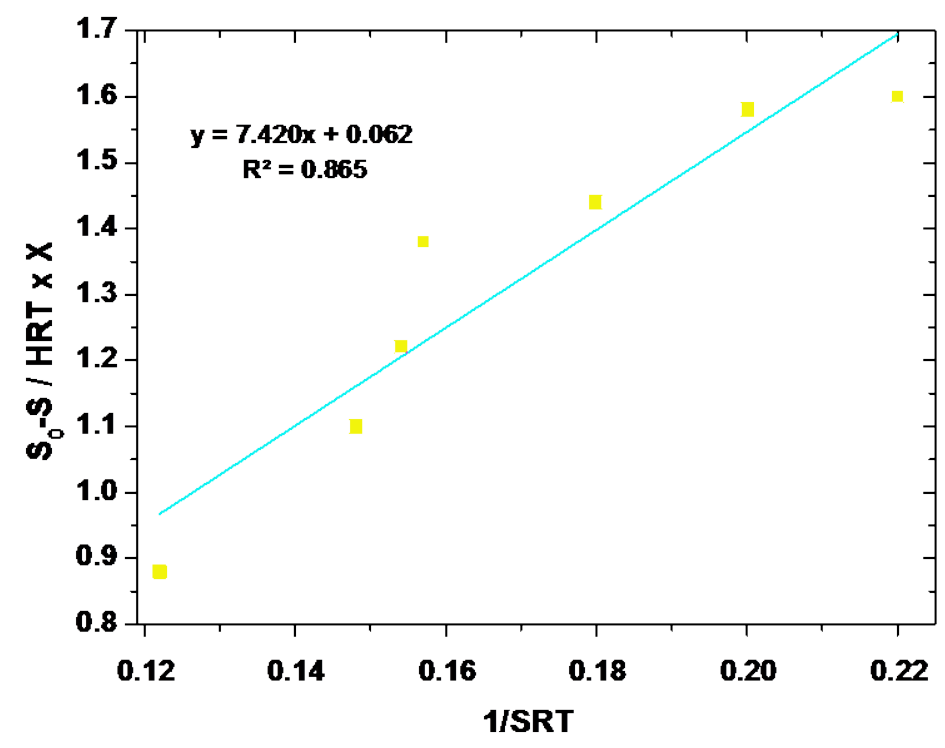


Figure 5. Linear regression between 1/SRT and $\left(\frac{\mathrm{S}_{0}-\mathrm{S}}{\operatorname{HRT}\left(\theta_{\mathrm{H}}\right) \times \mathrm{X}}\right)$ in December.

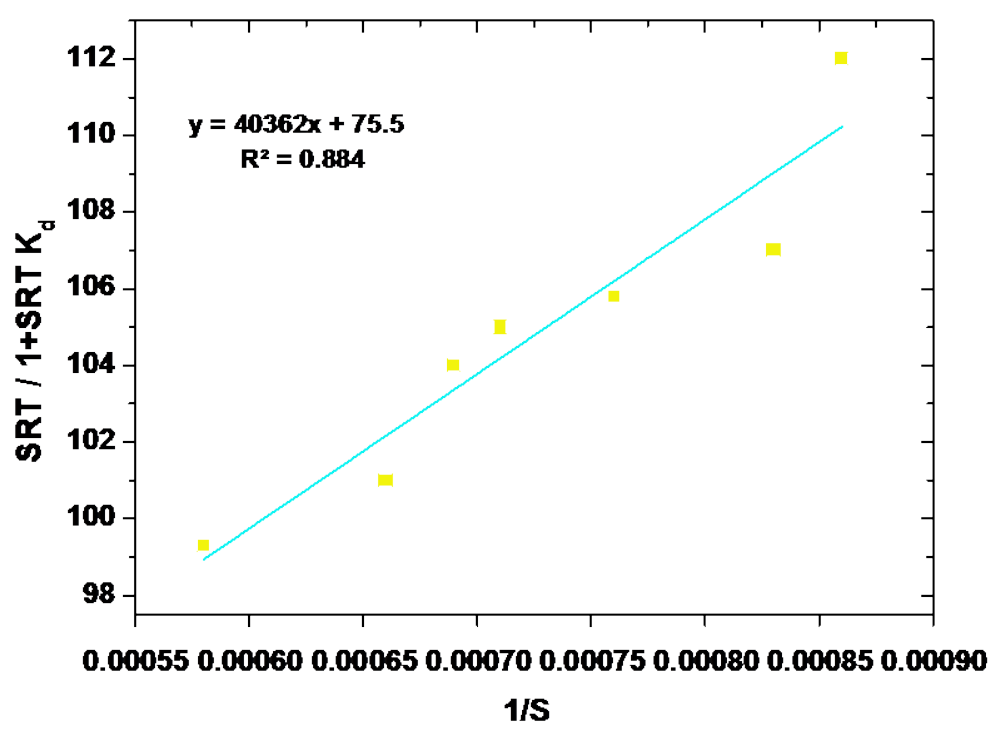

Figure 6. Linear regression between $1 / \mathrm{S}$ and $\left(\frac{\operatorname{SRT}\left(\theta_{\mathrm{C}}\right)}{1+\operatorname{SRT}\left(\theta_{\mathrm{C}}\right) \times \mathrm{X}}\right)$ in December

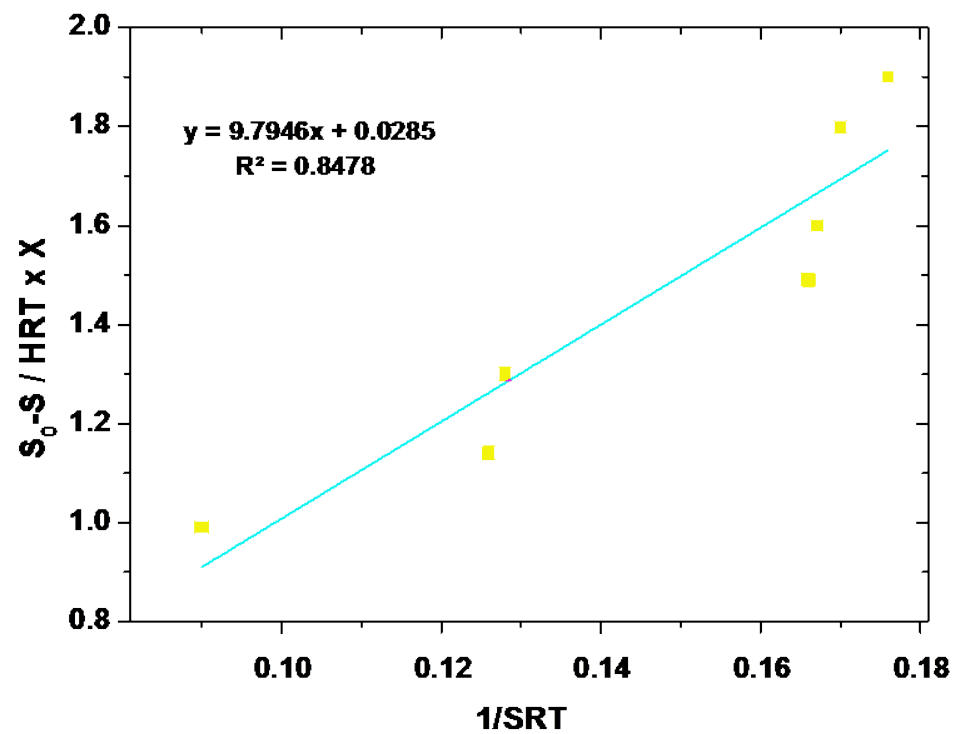

Figure 7. Linear regression between $1 / \mathrm{SRT}$ and $\left(\frac{\mathrm{S}_{0}-\mathrm{S}}{\operatorname{HRT}\left(\theta_{\mathrm{H}}\right) \times \mathrm{X}}\right)$ in January. 


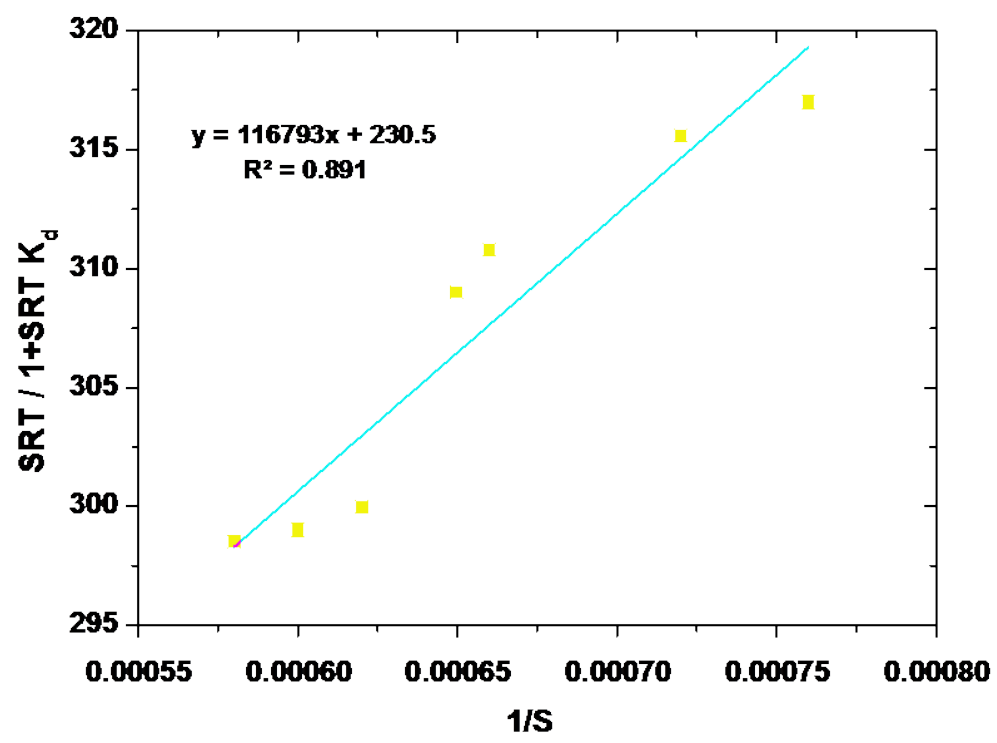

Figure 8. Linear regression between $1 / \mathrm{S}$ and $\left(\frac{\operatorname{SRT}\left(\theta_{\mathrm{C}}\right)}{1+\operatorname{SRT}\left(\theta_{\mathrm{C}}\right) \times \mathrm{X}}\right)$ in January

Considering the Figures 5 and 6 the values of kinetic coefficients $Y, K_{d}, K_{s}, \mu_{\max }$ and $K_{\max }$ in December were calculated as $0.013 \mathrm{~g}$ VSS/g COD, $0.134 \mathrm{~d}^{-1}, 527.9 \mathrm{mg} / \mathrm{L}, 0.0083 \mathrm{~d}^{-1}$, and $0.09 \mathrm{~d}^{-1}$, respectively. Table 7 displays the kinetic coefficients obtained in November, December, and January in the UASB system of wastewater treatment plant of sugarcane industry.

Table 7

Kinetic coefficients obtained in November, December, and January.

\begin{tabular}{lccccc}
\hline \multicolumn{1}{c}{ Months } & $\begin{array}{c}\boldsymbol{\mu}_{\max } \\
\left(\mathbf{d}^{-\mathbf{1}}\right)\end{array}$ & $\begin{array}{c}\mathbf{Y} \\
\mathbf{( k g ~ V S S / \mathbf { k g }} \\
\mathbf{C O D})\end{array}$ & $\begin{array}{c}\mathbf{K}_{\mathbf{d}} \\
\left.\mathbf{( d}^{-\mathbf{1}}\right)\end{array}$ & $\begin{array}{c}\mathbf{K s} \\
(\mathbf{m g} / \mathbf{L})\end{array}$ & $\begin{array}{c}\mathbf{K}_{\max } \\
\left(\mathbf{d}^{-\mathbf{1}}\right)\end{array}$ \\
\hline November & 0.0035 & 0.105 & 0.0024 & 484.9 & 0.033 \\
December & 0.0083 & 0.013 & 0.1340 & 527.9 & 0.090 \\
January & 0.0029 & 0.043 & 0.1020 & 506.6 & 0.042 \\
\hline
\end{tabular}


The results of the research showed that changes of concentration of organic matters entering the treatment plant were insignificant, so that the total mean of organic matters (COD) of raw sewage was $4288.5 \pm 438 \mathrm{mg} / \mathrm{L}$ in November, $4600 \pm 775 \mathrm{mg} / \mathrm{L}$ in December and $4597 \pm 418 \mathrm{mg} / \mathrm{L}$ in January and this value in December was higher than in the other studied months. BOD/COD ratio of raw sewage entering the treatment system was 0.42 to 0.49 in all three months, which indicates the degradability of raw sewage entering the wastewater treatment plant.

The mean of self-destructive coefficient $K_{d}$ in the studied months is equal to 0.086, which is within the range of other similar studies in UASB systems. This value indicates the lack of growth inhibiting factor in the raw sewage entering the biological treatment system. Brito et al. (Brito and Melo 1997) investigated the performance of UASB reactor in wastewater treatment plant of slaughterhouse and calculated the self-destructive coefficient of $\mathrm{K}_{\mathrm{d}}$ equal to $0.029 \mathrm{~d}^{-1}$. Moreover they calculated other kinetic coefficients of $\mathrm{k}, \mathrm{K}_{\mathrm{s}}, \mathrm{Y}$ as $5.1 \mathrm{~d}^{-}$ ${ }^{1}, 1.47 \mathrm{~kg} / \mathrm{COD}$, and $0.17 \mathrm{~kg}$ VSS/ kg COD, respectively.

Borjai and Bank (Borjai and Banks 1994) did some research on the effluents of ice cream manufacturing company in pilot scale and calculated the $\mathrm{K}_{\mathrm{d}}$ coefficient as $0.028 \mathrm{~d}^{-1}$, and the coefficients of $\mathrm{Y}, \mathrm{Ks}$, and $\mathrm{K}$ as $0.16 \mathrm{~kg} \mathrm{VSS} / \mathrm{kg} \mathrm{COD}, 1.39 \mathrm{mg} / \mathrm{L}$, and $0.29 \mathrm{~d}^{-1}$, respectively. Y coefficient or the coefficient of cell mass production in December was minimal by $0.043 \mathrm{~kg}$ VSS $/ \mathrm{kg}$ COD and the highest amount of produced sludge in November was equal to $0.105 \mathrm{~kg}$ VSS $/ \mathrm{kg}$ COD. There is an inverse relation between the maximum specific growth rate coefficient $\left(\mu_{\max }\right)$ and half saturation coefficient $\left(K_{s}\right)$, so that the higher the rate of half saturated substrate $\left(\mathrm{K}_{\mathrm{s}}\right)$ is, the lower the biological activity or specific growth rate $\left(\mu_{\max }\right)$ will be and the biological treatment efficiency will decrease. In this research, the maximum coefficient of specific growth $\mu_{\max }$ and the maximum rate of degradation $\mathrm{K}_{\max }$ in December were higher than other studied months which indicate high efficiency of removal 
of biodegradable organic matter $\left(\mathrm{BOD}_{5}\right)$ in December rather than the other months. In this study, the efficiency of COD removal increased from $61.5 \%$ in November by organic loading rate of $3.67 \mathrm{~kg} \mathrm{COD} / \mathrm{m}^{3} \mathrm{~d}$ to $69.8 \%$ in December by organic loading rate of $2.11 \mathrm{~kg}$ COD m${ }^{3}$ d. The hydraulic retention time was constant and equal to $12 \mathrm{~h}$ in the studied months.

With respect to the constant temperature of wastewater temperature entering the UASB biological treatment system, the tangible reduction of BOD and COD removal efficiency of biological treatment system in December can be associated with the increase of factory activity and the increased concentration of produced wastewater in different units of the factory. The generated wastewater in units of producing sugar and animal food and industrial board contains oil compounds, phosphate compounds, and sugar compounds resulting from the extraction of molasses from sugar which can increase the organic load so that organic loading in November has increased by $3.67 \mathrm{~kg} / \mathrm{d}$ for each one cubic meter of UASB volume compared with December and January. As the sugarcane harvest is interrupted in December and January due to climatic conditions, the activity of sugar manufacturing factory is reduced and less wastewater with organic load is generated. The rate of organic loading in biological treatment system reduced by $2.11 \pm 0.2$ and $2.97 \pm 0.3$ in December and January, respectively which resulted in the increase of BOD and COD removal efficiency in biological treatment system within the mentioned months. In addition to the effect of wastewater concentration on the removal efficiency, concentration of mixed liquid suspended solids (MLSS) also has a significant impact on the removal efficiency of biological treatment system. Table 8 shows the concentration of mixed liquid suspended solids (MLSS) in November, December, and January which is equal to $4980 \pm 1499$, 5916 \pm 1609 , and $5566 \pm 1552$, respectively. Therefore, the obtained results indicate that the increase of the rate of MLSS in biological treatment system influences the increase of removal efficiency of BOD and COD in filtration system. In order to increase BOD and COD removal efficiency of 
treatment plant system, different parts of the factory can promote the performance of biological treatment system through the primary wastewater treatment such as using fatconsuming materials or using septic in the path of wastewater and through accurate identification of materials produced by different units of the factory in various months of the year.

Isik and Sponza (Işik and Sponza 2005) investigated the UASB reactor performance for the removal of azo dyes and salts and other additives from the simulated textile effluent in laboratory scale and calculated the kinetic coefficients of $\mathrm{K}_{\mathrm{s}}, \mathrm{K}_{\mathrm{d}}, \mathrm{Y}$, and $\mu_{\max }$ as $10338 \mathrm{mg} / \mathrm{L}$, $0.0065 \mathrm{~d}^{-1}, 0.125 \mathrm{mg}$ VSS/mg COD, and $0.105 \mathrm{~d}^{-1}$, respectively. Perez et al. (Pérez et al. 2012) evaluated the UASB reactor performance in wastewater treatment and calculated the kinetic coefficients of $\mathrm{K}_{\mathrm{s}}, \mathrm{K}_{\mathrm{d}}, \mathrm{Y}, \mu_{\max }$ and $\mathrm{K}$ as $214 \mathrm{mg} / \mathrm{L}, 0.0023 \mathrm{~d}^{-1}, 0.0767 \mathrm{~kg} / \mathrm{VSS} / \mathrm{kg}$ COD, $0.0198 \mathrm{~d}^{-1}$, and $0.257 \mathrm{~d}^{-1}$, respectively and the suggested coefficients in the research were developed successfully. Usually, the kinetic coefficients in various studies are very different for different kinds of industrial effluents. Even in similar studies, the coefficients are slightly different based on the quality of input wastewater and the kind of treatment system and the difference results from operating conditions and changing quality of input substrate and their changes. In this research by changing factors such as input substrates (BOD and COD), different organic loads entering the reactor, and also biomass concentration changes in UASB reactor during the study, different kinetic coefficients were obtained. The summary of obtained results is presented in Table 7.

In general, the results of the research can be used for the prediction of UASB system performance and determination of kinetic coefficients $\mathrm{Y}, \mathrm{K}_{\mathrm{d}}, \mu_{\max }, \mathrm{K}_{\mathrm{s}}$, and $\mu$ in UASB reactor in full scale for similar industries. 


\section{Conclusion}

In this present work, the determined models are properly adjusted and consequently consistent.The kinetic parameters estimated in the UASB reactor were: limiting substrate concentration $\mathrm{K}_{\mathrm{s}}=506.4 \mathrm{mg} / \mathrm{L}$, yield coefficient $\mathrm{Y}=0.053 \mathrm{~g} \mathrm{VSS} / \mathrm{g}$ COD, decay coefficient $\mathrm{K}_{\mathrm{d}}=0.086 \mathrm{~d}^{-1}$, maximum growth rate $\mu_{\max }=0.0049 \mathrm{~d}^{-1}$ and $\mathrm{K}_{\max }=0.055 \mathrm{~d}^{-1}$. The mean of organic loading entering the UASB reactor is equal to $2.91 \mathrm{~kg} \mathrm{COD} / \mathrm{m}^{3} \mathrm{~d}$ and the mean of BOD removal efficiency is $66.1 \%$. The obtained results in this study indicate the appropriate performance of UASB treatment system. Furthermore, this system can be used as an appropriate pretreatment before the active aerobic treatment systems of sludge for the wastewater treatment of sugarcane industry. The kinetic coefficients obtained in this research can be used in management, operation, and design of similar treatment plants of sugarcane industry.

\section{Acknowledgment}

The managing director of Imam Khomeini (pbuh) Agro-Industry in Shooshtar and the laboratory expert of Agro-Industry Treatment Plant are highly thanked for their cooperation in conducting this research.

\section{References}

Anderson GK, Kasapgil B, Ince O (1996) Microbial kinetics of a membrane anaerobic reactor system Environmental Technology 17:449-464

APHA, AWWA, WEF (2005) Standard Methods for the Examination of Water and Wastewater. In., 21 edn. American Public Health Association Publication, Washington, U.S.A.,

Borjai R, Banks CJ (1994) Kinetics Of An Up flow An Aerobic Sludge Blanket Reactor Treating Ice-Cream Waste Water Environ Sci Health 29:2063-2085

Brito AG, Melo LF (1997) A simplified analysis of reaction and mass transfer in uasb and egsb reactors Environmental Technology (United Kingdom) 18:35-44 doi:10.1080/09593331808616510 
Campos CMM, B. SB, Carmo FR (2005) Determination of kinetic parameters of a lab-scale upflow Anaerobic sludge blanket reator (UASB) removing organic Loading from swine manure effluents Revista Agrociência 29:1045-1051

Fazelipour M, Takdastan A, Jou MSS (2011) Survey on chlorine application in sequencing batch reactor waste sludge in order to sludge minimization Asian J Chem 23:29942998

Işik M, Sponza DT (2005) Substrate removal kinetics in an upflow anaerobic sludge blanket reactor decolorising simulated textile wastewater Process Biochem 40:1189-1198 doi:10.1016/j.procbio.2004.04.014

Iza J, Colleran E, Paris JM, Wu WM (1991) International workshop on anaerobic treatment technology for municipal and industrial wastewaters: Summary paper Water Sci Technol 24:1-16

Jaafari J et al. (2017) Simultaneous biological organic matter and nutrient removal in an anaerobic/anoxic/oxic (A2O) moving bed biofilm reactor (MBBR) integrated system International Journal of Environmental Science and Technology 14:291-304

Masse L, Massé DI (2010) The effect of environmental and process parameters on flocculation treatment of high dry matter swine manure with polymers Bioresour Technol 101:6304-6308 doi:10.1016/j.biortech.2010.03.037

Mirzaiy A, Takdastan A, Alavi N, Mohamadian H (2012) Removal of Turbidity, Organic Matter, Coliform and Heterotrophic Bacteria by Coagulants Poly Aluminium Chloride from Karoon River Water in Iran Asian J Chem 24:2389-2393

Mosavian S, Takdastan A (2014) Determination of Kinetic Coefficients in Up-flow Anaerobic Sludge Blanket Using Industrial Wastewater Journal of water and waste water 2:62-70

Mostaed S, Amin MM, Hassani A, Takdastan A (2010) Anaerobic biofilm reactor systemefficiency in sugar cane industry wastewater treatment Journal of the Health System and Research 6:1002-1014

Mousavian S, Takdastan A, Seyedsalehi M, Akhavani S (2016) Determining the Kinetic's Coefficients in Treatment of Sugarcane Industry Using Aerobic Activated Sludge by Complete-Mix Regime Journal of Chemical and Pharmaceutical Research 8:13421349

Nejad MH, Takdastan A, Jaafarzadeh N, Mogadam MA, Mengelizadeh N (2013) Removal of orthophosphate from municipal wastewater using chemical precipitation process in ahvaz wastewater treatment plant, Iran Asian J Chem 25:2565-2568

Osaloo A, Khoushfetrat A (2004) Process of biological removal of volatile organic compounds in wastewater treatment plant aeration basin petrochemical 9th National Conference on Engineering Chemistry, Iran University of Science and Technology, Iran

Pazoki M, Takdastan A, Jaafarzadeh N (2010) Investigation of minimization of excess sludge production in sequencing batch reactor by heating some sludge Asian J Chem 22:1751-1759

Pérez J, Aldana G, Cárdenas C (2012) Upflow anaerobic sludge blanket reactor (UASB) performance through sludge age load and kinetic coefficients Rev Tec IngUnv Zulia 35:98-108

Rodríguez-Gómez R (2013) A model to Predict the Behavior of UASB Reactors Int J Environ Res 7:605-614

Seghezzo L (2004) Anaerobic Treatment of Domestic Wastewater in Subtropical Regions PhD Dissertation, Wageningen University, Wageningen

Seyedsalehi M et al. (2017) Evaluation of moving-bed biofilm sequencing batch reactor (MBSBR) in operating A2O process with emphasis on biological removal of 
nutrients existing in wastewater Int $\mathrm{J}$ Environ Sci Technol:in press, doi: 10.1007/s13762-13017-11360-13769

Takdastan A, Azimi AA, Jaafarzadeh N (2010) Biological excess sludge reduction in municipal wastewater treatment by chlorine Asian J Chem 22:1665-1674

Takdastan A, Mehrdadi N, Torabian A, Azimi AA, Bidhendi GN (2009) Investigation of excess biological sludge reduction in sequencing bach reactor Asian $\mathrm{J}$ Chem 21:2419-2427

Tauzene M, Milton C (2011) Determination of Kinetic Parameters of an Up-flow Anaerobic Sludge Blanked Reactor (UASB), Treating Swine Waste water Ciênc agrotec,Lavras, 35:1204-1210

Tchobanoglous G, Burton FL, Stensel HD (2003) Wastewater Engineering: Treatment, Disposal, and Reuse. McGraw-Hill, New York, USA

Van Haandel A, Kato MT, Calvacanti PFF, Florencio L (2006) Anaerobic reactor design concepts for the treatment of domestic wastewater Reviews in Environmental Science and Biotechnology 5:21-38 